\title{
Ideology and Economic Activity
}

\author{
by \\ Michio Morishima \\ London School of Economics and Political Science
}

Discussion Paper

No. JS/86/142

1986
The Suntory Centre

Suntory and Toyota International Centres for Economics and Related Disciplines London School of Economics and Political Science Houghton Street, London, WC2A 2AE, UK. Tel. 020-7955 6698

\footnotetext{
"A survey article for a "State of the Art" volume for the area of Economy and Society, edited by Neil Smelser and Alberto Martinelli.
}

NB: This PDF was retrospectively created in February 2004 of the STICERD discussion paper previously published in 1986. 


\section{Abstract}

In considering ideology and economic activity, ideology is defined as a system of beliefs which binds people together into a social grouping. This is synonymous with religion as defined by Durkheim (1912) and, as a definition of religion, it may be too wide; but if this definition is adopted, both Confucianism and Marxism are 'religion'. In any case, there are two broad-based classes of approach to this problem, Marxian and Weberian. The former regards ideology which, together with such institutions as the state, family structure, etc., constitute the superstructure of the society, as being no more than a reflection of underlying basic material conditions. The latter, on the other hand, approaches from the superstructure to the base and establishes the reverse relationship. As will be seen later, neither of the two approaches alone can serve for the intepretation of a social historical process. To achieve this we must use both approaches and examine interdependence and interaction between materialistic or economic factors, and ideological or religious ones.

Keywords: Ideology, economic activity, social groups, religion, institutions, Confucianism, Marx, Weber, historical process.

(C) by Michio Morishima. All rights reserved. Short sections of text, not to exceed two paragraphs, may be quoted without explicit permission provided that full credit, including $\odot$ notice, is given to the source. 


\section{IDEOLOGY AND ECONONIC ACTIVITY}

1. In considering Ideology and economic activity, ideology is defined as a system of beliefs which binds people together into a social grouping. This is synonymous with religion as defined by Durkhefm (1912) and, as a definition of religior, it may be too wide; but if this definition is adopted, both Confuclanism and Marxism are 'religion'. In any case, there are two broad classes of approach to this problem, Marxian and Weberian. The former regards ideology which, together with such institutions as the state, family structure etc., constitute the superstructure of the society, as being no more than a reflection of underlying basic material conditions. The latter, on the other hand, approaches from the superstructure to the base and establishes the reverse relationship. Obviously no comment is needed on the Importance of the Marxian approach, while the following passage from Weber (1930, pp. 68-69) serves to fustify his approach:

"The question of the motive forces in the expansion of modern capitalism is not in the first instance a question of the orfin of the capital sums which were available for capitalistic uses, but, above all, of the development of the spirit of capitalism. Where tt appears and is able to work itself out, it produces its own capital and monetary supplies as the means to its ends, but the reverse is not true."

As will be seen later, neither of the two approziches alone can serve for the interpretation of a total historical process. To achieve this we must use both approaches and examine interdependence and interaction between materialistic or economic factors and ideological or religious factors. In fact, as Weber himself acknowledges, the Weberian approach is compatible with the Marxian; they would and 
should eventually be synthesized with each other, though the task is extremely difficult and complicated.

Economic theory, Marxist or non-Marxist, assumes the rational man of the Robinson Crusoe type, hardworking, materialistic and purposefully systematic. Crusoe is an Englishnan born in 1632, just before the English Revolution, his father being a native of Bremen who settled at Hull; he would probably have been a Protestant. Economists entirely ignore his religious background as well as the Zeitgeist of the 17 th century. Economic laws deduced from a model consisting of Robinson Crusoe consumers and firms owned and operated by Robinson Cxusoe families are applied not only to European and American economies but also often to non-occidental industrial societies, such as Japan, or even to less developed countries.

For example, Guha (1981) follows the Marxian method and compares Russia, Japan, India, and China in economic development. He is seldom concerned with differences in the religious attitudes of the peoples of these countries, so that they are viewed as if they speak the same language, have the same degree of infustriousness and are provided with the same kind of ethos. Guha refers to the industrial revolution which occurred in Manchuria during the 1930 s $^{1}$ but makes no mention of the fact that it was mainly carried out by Japanese. Although Chinese, Manchurians, Mongolians, and Koreans also lived in Manchuria, it was the Japanese who established modern industries there. Of course, these Japanese were driven along by the forces of imperialism and militarism, but it must not be forgotten that of these peoples the Japanese had the most highly developed spirit of capitalism. 
Dore (1976) may also be considered as tending towards the 'Marxist' approach, although he pays some atterition to the Weberian approach too. Comparing education in Britain, Japan, Sri Lanka and Kenya, Dore concludes that the later the point in world history a country starts on a modernization drive, the stconger the desire for educational qualification to become entrenched and the more qualification-orientated schooling becomes at the expense of genuine education. In deriving this general tendency Dore bases his argument on the fact that countries in the developing world are usually constructed of dual components, i.e. a rich modern sector, on the one hand, and an impoverished traditional sector on the other. The later development starts, the more the tendency to dualism is exacerbated, and those organisations belonging to the modern sector - central and local government, large multinational corporations and big private firms - usually tend to recruit by certificates. Of course, this law only operates on the assumption that other things are equal, but because the concepts Dore uses are "basic" in the sense that they can be applied to all nations, the cultural and sociological elements specific to individual nations are considered merely as "other things". In Dore, therefore, the examination of the effects of superstructural elements upon the basic tendencies is minimized. Since Dore has looked at cultural differences between Japan and Britain too, it would, strictly speaking, be unfair to say that he ignores the effects of the superstructure, but it seems at least to me that he has not sufficiently emphasized the significance of these effects. 2

Dore mentions that the Japan of the immediate pre-industrial period was a Confucian country where learning and scholarship carried high prestige and "the very idea of education, therefore, was given 
higher value than in Britain's more philistine society".3 Confucianism, however, is firmly rooted in Japan; and goes back far beyond the immediate pre-industrial period; it has been the moral backbone of the Japanese people since the ancient time of shotoku Taishi (573-621). While contemporary Japanese are perhaps more hideously and vulgarly philistine than the British, they are still Confucian in the sense that they classify people into two classes, illiterates (small men) and literati (gentlemen). The educational. rat race in Japan is primarily a rat race to be classified as an educated gentleman, and not an economic race in pursuit of a higher income, although income is usually obtained in proportion to achievement in the educational race. This isi evident from the case of female students, because in Japan most girls work only for a few years after college or university, yet the educational rat race among them is as severe as that among boys. It is obvious that girls take part in the entrance examination to colleges and universities, not for better jobs after graduation but to be themselves classified as a member of the upper tier of a dual structured society; without this, it is very difficult for them to marry a man in the upper tier. Women's colleges in Japan are institutions for deciding students' social standing. Like finishing schools in B:itain they are neither academic nor vocational-educational, except for a few. Likewise for boys, degrees and diplomas play a role similar to that played by genealogical charts and records in the medieval age. Firms recruit new members from the "gentleman" class; in Confucian Japan candidates must be able to show diplomas in order to establish their identity as a member of that class. In fact, both boys and girls can obtain a high social standing, if they receive higher education, while they 
can easily lose thelr parents' high standing if: they fail to go on to a university.

On the other hand, Dore emphasizes the fact that there was no systematic general education in Britian at the time of the industrial revolution. This revolution was accomplished by craftsman-inventors, mill-owners and so on, who had only a basic education and little specialized, scientific and technological knowledge. It seems to me, however, that what we need to explain, is why general education remained so poor in Britain until the late 18 th century that the industrial revolution had to be achieved mainly by dextrous fingers. A partial explanation may lie in the long tradition of primogeniture in England, which meant that children other than the heirs of the parents' land had to become independent at a very early stage of their life. A typical child "is early sent to school, but at fourteen leaves home to earn his living ... he goes to the nearest country town and stands in the market place [for a job].... At sixteen or seventeen he is stalwart enough to hire as a man, and now his wages are doubled. ... Many of the men, when about thirty years of age, are able to take small farms of theix onn". 4 This has been a typical life style among English lads since the 14 th or 15 th century. In this way, "the younger sons of the gentry, apprenticed to London masters, rose to be City managers." 5 Even the eldest son went away $\checkmark$ for several years before returning to take over a holding. "The Statute of Artificers (1563) enacted that every craftsman in town or country had for seven years to learn his craft under a master who was responsible for him. "6 Thus, for many centuries apprenticeship was a substitute for school in England. Behind tine fact that higher education has not been of particular conceyn in England 1ies the 
spirit of independence of English youth, of English individualism. This has been one of the most powerful driving forces in this country, and the existence of such a factor has not been emphasized by Dore. This big difference in spirits observable between Japan and England, that is, Confucian class consciousness vs. English individualism, offers a basis for developing a Weberian spiritualistic analysis, and such a consideration is necessary to complete Dore's materialistic analysis.

2. Weber's studies in ideology, relig;ion and ethics (or the national ethos nurtured by them) and their effects upon the people's secular life and economic activity, the stuites which I call "social ethology", are contained in the three volumes of his Gesammelte Aufsatze zur Religionssoziologie, chapter rV of his wirtschaft und Gesellschaft and part IV of his Wirtschaftsyeschichte. of these the work of the Protestant ethic is of course the most famous and controversial. There are many critics of this long treatise, the most significant including Brentano (1923) and Tawney (1977, first published in 1922). The controversy is surveyed by Fischoff (1968).

Weber's critics are mainly concerned with the following points.7 (i) It would be untrue to say that the Protestant (or Puritan) Reform was necessary for the appearance of capitalist enterprises - the woollen towns such as Ghent, Bruges and Mechlin in Flanders as well as Venetian and Florentine capitalism nad already flourished in the 14 th and 15 th centuries 8 .- whereas it would be equally untrue to say that the religious-reforms were produced as a result of the progress in the material lives of human beings. (ii) Weber failed to appreciate intellectual movements, other than religious ones, which contributed ta the promotion of indivicuals' rational economic 
behaviour. Brentano and Tawney point out that Machiavelli was at least as influential as Calvin. The studies made by $\mathrm{St}$. Antonine of Florence on economic activity and processes 9 were a second element which Weber ignored. (iii) Weber seems to have over-simplified both 'the Protestant ethic' and 'the sptrit of capilalism'. Tawney says that the Calvinists of the 16 th century were believers in a rigorous discipline and would be horrified by the individualism ascribed to the Puritan movement in the 17 th. Weber left unexplained what caused this change. 10

Hirschmeier and Yui (1975) compare the spirit of the merchant class of Tokugawa Japan with that of the city nerchants in Renaissance Italy. By emphasizing the fact that capitalist activity was vigorous in Catholic Italy before the Lutker-Calvin age, these authors seem to be making a similar criticism to that of point (i) above. 11 Schumpeter (1954) directs his attertion to a different point. According to him, Weber's problem is "at typical instance of what may be termed spurious Problems". In view of the fact that Weber's concepts of feudalism, capitalism, etc. are all ideal types, his problem of transforming feudalism to capitalism is a problem of replacing the 'ideal' Feudal Man by the 'idtal' Capitalist Man, nether of which have any counterpart at all in the sphere of historical fact. Thus, "the problem of what it was that turned the one into the other vanishes completely."12 Similar criticisms as those alleged by Brentano-Tawney, Hirschmeier-Yui, and Schumpeter above could all be made mutatis mutandis concerning Weber's other works, "Ancient Judaism", "Confucianism and Taoism", "Hinduism and Buddhism" and "Islam". 
It is true that in Weber's work both "Protestant ethic" and "the spirit of capitalism" are concepts constructed on the basis of an ideal-type. However, as was made clear by otsuka (1955), Weber carefully distinguished between "the spirit of capitalism" and "the capitalist spirit", the latter being the greediness for money of merchants and usurers, military contractors, firancial magnates etc. which is seen everywhere in the world and is as old as the history of human beings. By "the spirit of capitalism", on the other hand, Weber meant the spirit of the modern capitalist regime (that is, "the attitude which seeks profit rationally and systematically as the calling or job"13) and had no intention of apply:ing it to "capitalism [as] existed in China, India, Babylon, in the clissical world, and in the Middle Ages". 14 In all these cases, Weber explicitly said, this particular ethos was lacking. 15 It is evident, therefore, that criticism (i) by Brentano-Tawney as well as that made by Hirschmeier-Yui are both off the point.

Weber was concerned neither with the origination of capitalism nor with modern capitalism nor with the transformation of feudalism to capitalism. His theory is not a causal analysis of history at a11. We must, therefore, say that schumpeter too has missed the point. What Weber aimed to accomplish was to reveal, by use of the ideal typical analysis, that there is a deep internal relationship between Protestantism and the ethos of modern capitalism in as far as the former is suited to the promotion and enhancement of the latter, so that it could have played the role of a driving force of of capitalism. (See- Otsuka (1955).) Similarly Fischoff (1968) summarizes what Weber intended to clarify to the same effect: that is, "it was the spirit af a 'methodical' Lebensfuhrung which he (Max Weber) was deriving from Protestant ascetism and which is related to 
economic forms only through congruence (Adäquanz)".16 Point (ii) raised by Brentano and Tawney is not a criticism of Weber but merely an indication of another problem. He was perfectly entitled to neglect all the non-religious intellectual movements following the Renaissance for the simple reason that he was not interested in then, although he would have had to take them into consideration if he had been concerned with a causal investigation of the emergence of capitalism.

Despite this, we must acknowledge Brentano':s and Tawney's point (iii). However, this does not mean that Weber's analysis was wrong; it only implies that it was imperfect. We construct various ideal types on the basis of historical, sociological or economical observations and examine the logical, phenomenological or interpretive interrelationships existing between these ideal types. We have to begin with a simple conceptual scheme from which only an over-simplified picture can be obtained. By using a more complicated scheme of ideal types, however, we may always arrive at a better understanding of the history or the society. Thus Weber is a base for further development, i.e. a first approximation.

3. Why did "modern capitalism" not emerge in other times and other places than modern western Europe? It wasi Weber's belief that modern capitalism was not automatically produced by the development of science and technology. Behind its emergence was also the emergence of rational, anti-traditional way of thinking among human agents. He asked why there had been an enormous historical difference in this respect between the Orient and the Occident. For the purpose of answering this question he made a magnificent comparative study covering Europe, the Middle East, India and China and concluded that the modern Occident was provided with religious elements which are 
favourable for the rise of capitalism, whila such elements were absent in other civilisations. He states, in connection with China, that "genuine prophecy creates from within a way of life systematically oxiented towards a single scale of values, and in the light of such an orientation the world is regaried as raw material to be shaped in ettical terms according to the given norm".17 Confucianism is the reverse of this. Weber considers that, like Protestantism, Confucianism is a highly rational religion, but there is an important contrast between them. "As aga:nst the accomrodation to the world found in Confucianism we find in Puritanism [or Protestantism] the task of reorganising the world in a rational manner". 18 Thus, whilst "rationalism" is contained in the spirit of both ethics, the confucian rationality is different from that of Puritanism: "Confucian rationalism signified rational accommodation to the world: Puritan rationalism rational control of the world". I9 It was only the latter which fostered modern natural science and promoted the spirit of capitalism. In China, not only were natural science and technology absent, but also natural law and formal logic. China, therefore, failed to achieve a shif: from empirical to rational techniques. "Everything remained at the level of sublimated empiricism". 20

Each religion has a social class which supports that religion and, therefore, exerts a decisive influence on its development and propagation. In the case of Confucianism, it was the mandarins "earthly, rational stipend-holders of literary qualifications". whilst in the case of Hinduism and Buddhism, j.t was the hereditary Brahman caste with its knowledge of the holy books, the Vedas, and also the ascetic and meditative wondering mendicant friars. (In the 
case of Christianity it was itinerant craftsmen or urban citizens.) Moreover, in India the society is deeply divided into countless castes, sects, speech and biood groups. Almost without exception, metaphysical promises given by Indian doctrines of salvation are only accessible to those of the Brahman caste or those living monastically, though some were valid for the general populace. In India, as in China, there is a deep gulf between the educated few and the illiterate mass of philistines, and knowledge is the single absolute path to the highest holiness in this world. Indians, however, differ from and are more faithful than Chinese in believing that this rule applies to the world beyond too.

Because of this very strong and strict duali:sm dividing society into two strata, the wise and educated few and the uncivilized plebeian masses, "the factual, inner orders of the real world, that is, nature and art alike, ethics and economics alike, remained concealed from noble men, since these things were so barren as far as their particular interests were concerned. Their way of life was oriented, in striving for extraordinary things, to the example set by their prophets and wise men who were their absolute exemplars in every major respect. For the plebeian, however, there was no prophecy of ethical mission which would serve as rational formulation for their everyday life".21 As the elite was so taken up with metaphysics and the plebeians so ignorant, one could not expect modern capitalism to emerge in India indigenously and autonomously; the natural social sciences have been of poor quality in India throughout her history, whereas magic and metaphysics have always been rich and prosperous. The imbalance between theoretical and practical statistics in India is a mere symptom of the intellectual 
polarization prevailing in the society.

Weber's whole comparative study of world religions may be regarded, as he himself perceived, as a massive unified work aimed at clarifying the cultural background, spiritial backbone and the materialistic consequences of Occidental civilisation. From a different point of view, however, it may be seen as part of the overall task of establishing the proposition that the economic performances of various peoples or nations are unstable and influenced by the slightest change in their ethos. Only that part concerning Christianity was completed by Weber himself, but he can be considered as having left unfinished the parts relating to other religions, e.g. Confucianism, Hinduism, Buddhism.

The instability (or knife-edge) thesis is based on the observation that Catholics and Protestants, who share the same Bible but interpret it differently, are significantly different in their modes of worldly behaviour. Weber sees the essential disagreement between the two as lying in the fact that Prctestantism removes the barrier between layman and clergy by discarding the division of Christian ethical precepts into praecepta and consilia, while Catholicism sticks to this dualism. For all Protestant denominations "the only way of living acceptable to God was not to outbid worldly morality by monastic ascetism, but solely through the fulfilment of the obligations imposed upon the individual ty his position in the world. That was his calling". 22 Thus, by interpreting the same Bible differently Protestantism produces the concept of a job as a "calling" i.e. a task set by God, by which secular life (therefore, economic activity) is connected with the will of God. Then one's job becomes one's duty, and this kind of outlook cm work is, at least in 
some stage of history, necessary for the establishment of the capitalist regime and its taking-off for economic growth. The Protestant Reform was a breakthrough by which aszetism, confined up to then within monasteries, was openly released into the outside secular world. People then began to act ascetically and rationally; the rational utilization of capital was carried out and the rational capitalistic organisation of labour was implemented. Protestantism thus contribtued to (or is congruent with) establishing an efficient economic system.

As for China and India, no such instability argument is found in Weber's works. He only concludes that none of Confucianism, Hinduism or Buddhism is suitable for promoting the spirit of capitalism; each contains some significant factors which work so as to prevent the emergence of capitalism. He is nearest to the knife-edge proposition when he says: "The Chinese in all probability wou.d be quite capable, probably as much as if not more capable thar. the Japanese, of assimilating capitalism which has technologicaliy and economically been fully developed in the modern culture area."23 In a book (1982), however, I have found a room for further investigation and developed, for the sake of comparison between China and Japan, an argument which is parallel to the one which Weber made with respect to Catholicism and Protestantism.

In my opinion, between China and Japan there: is prima facie no significant difference in ideological layout. They are primarily Confucianist countries; Buddhism came to Japan not directly from India but always through China, and Shintoism, which is generally thought of as a religion truly indigenous to Japan, was, even in its ancient primitive form, deeply influenced by Chinese Taoism; indeed 
it has been suggested that it might even be nothing other than a disguised Japanese version of Taoism. In spite of this, Japan succeeded in easily assimilating modern capitalism, while China continued to be exploited by imperialists from the West and Japan. This paradoxical situation can be resolved only by viewing it in the light of instability theory.

It is noticeable that whereas the Chinese interpretation of Confucius' doctrines is individualistc and humanistic, the Japanese one is nationalistic and militaristic. This contrast arguably has existed ever since Confucianism first came to Japan in about the 6th century. This is not surprising because the Japanese have suffered at all times from a sense of inferiority vis-à-vis the powerful Chinese empire, leading them to be, throughout their history, closely banded together and aggressive. 24 At the end of the period of isolation which lasted for more than 200 years up to 1859 , Japan was under pressure from the west. In this crisis the intelligentsia, who had been educated in the Japanese-Confucian manner, succeeded in unifying the country and finally established a new powerful modern government. It eventualiy established a nationalist-capitalist economy based on a seniority system, lifetime employment and the loyalty of employees to their company, which is a system perfectly fitting to the ethos of Japane:se Confucianism. 25

For the establishment of modern Western-style capitalism, there are two preconditions: the nation state and the civil society. In order for the capitalist mode of economic behaviour to prevail, an administrative organisation must be established, which secures the continuance of the regime. There must be a strong government which enforces rational law in order to enable each nember of the society 
to calculate the consquences of his activity objectively and quantitatively. The govermment must have professional bureaucrats, administrative, judicial and milltary. 26 It is very much due to the nationalistic Japanese form of Confucianism that Japan, which had been split into many segments classwise and regicnwise, was easily unified into a nation in a relatively short pericd of about twenty years, although there were obviously other favouable factors, such as Japan's being an island country and Japan's awareness that the Philippines had fallen into the hands of Spain and China was under constant attack from Western countries. In 1890 Japan already had powerful modern government with officials reciuited from anong ex-samurai and new university graduates.

It was, however, very difficult for Japan to fulfil the other precondition. In contrast with Christianity, azccording to which everyone is equal in the sight of God, Confucianism promotes a collectivist ethic and the ethics of functional role expectation, 27 both of which maintain and strengthen the hierarahical character of the society. Therefore, the elements of a civil society were not well developed in Meiji Japan, and it is evident that this strong nation with its weak civil society was not suited for the competitive capitalism of the Western type. It created a different type of production system, 28 though this can be inclided in the broad category of capitalism. In this economy, the invisible hand is more visible, since the government always takes the initiative and plays the role of helmsman of the economy. Efflclency has been established by collaboration rather than competition, and the idea of class antagonism has not been widespread among trade unionists. 
4. We may now say that by virtue of the emergence of Japan, capitalism can no longer be monochromatic. Moreover, as the capitalism of the West, which may be called Protestant capitalism, declines as Schumpeter has pointed out, 29 becaluse of its very achievements, its very success, so the Confucian capitalism looming in the East becomes more alarming. We will return to this later. The attainment of an economic optimum via individualistic economic competition, which is said to be the most important raisond'etre of the free enterprise system, is neither the main purpose nor the prime function of the Japanese economy. Not competition among workers vis-à-vis the firm, but collaboration between workers for the benefit of the firm becomes the more important subject for analysis. In fact, in Japanese society, competition prevails, not so much among adults, but mainly among children, who are selected and allocated to various firms according to the qualities of the diplomas they have received in the educational rat race; once they have been allocated to a firm, it is very difficult for them to move, especially from a small firm to a big one. In addition, Japanese society is a dual society; there is a big gulf, in wages, fringe benefits, productivity, risks and the rate of profit between the big business sector and the small business - subcontractor sector. Compared with Western firms Japanese big business operates in a very bureaucratic way, adopting the ringi system (the system of "proposal submission from below and deliberation at the top $\left.{ }^{n}\right)^{30}$ instead of the Western planning and decision making by top management. Moreover, the newly industrialized countries such as Korea, Taiwan, Hong Kong and Singapore are all dominated by Confucianism. For the analysis of these new capitalist societies, especially Korea, Taiwan and Japan, a 
new economic model emphasizing collaboration, group consciousness and nationalism should be formulated.

In order to analyse non-occidental economies Marx conceived the idea of the Asiatic mode of production. 31 In its typical form this mode of production develops in the vast areas of the world where the climate is intensely hot, so that such areas are likely to embrace huge tracts of desert. Land in these areas is virtualiy a free good, and for that reason the private ownership of liand does not exist. Irrigation and fertilization are the most important tasks of the state, and in these areas it is the state itself wich is the supreme landlord. In economic terms the people possess no power whatsoever vis-á-vis the ruler, and autocracy therefore prevails (Oriental Despotism). There is no question of the people in countries of this kind being civic in the western sense of the word.

Japan and the other new industrial countries of Asia are certainly not typical of the Asiatic mode of production. In the first place they are countries whose land areas aje small and where irrigation is not a matter of life and death. They are all seagoing nations possessing long coastlines in proportion to their total land areas. All have developed by means of foreign trade by sea. Yet the population of these countries is largely made up either of chinese or of people who have been conspicuously influencel by the culture of China, so their manners and customs are distinctively Chinese in a broad sense. In these countries, which have dereloped by acquiring the greatest possible demand for their goods from abroad; home demand is not very important in the context of their economic growth. An exception to this is Japan, which has fairly large home demand, but even in Japan domestic demand is not the main motive force behind 
development.

Therefore, in these countries the fact that a civil society fails to develop is not a serious matter; despite poor home demand from their poor civil societies they could still expand their economies. In this way, they embarked on a forced march of rapid growth to catch up with the West. In particular, the growth programmes of Japan and Korea have been formulated in such a way that the completely modernized industrial core produced within Japan or Korea was steadily expanded at all costs. The small business - subcontractor sector was a loser at all times; it was exploited and exoded by the big business sector which was supported by the state. For the forced march loyalty and service in the form of self-devotion to the state and the work place are required of the people, and throughout the period of modernization there has been little recognition that each individual has an innate right to freedon and self-enlightenment.

A strong nation state is a precondition both for capitalism and for socialism. It might be said that the nationalistic Japanese Confucianism which is not suited to the establishment of a civil society would probably accord more with socialism than capitalism. 32 At the time when the modern state was formed in Japan, however, socialism was available only as a theory, no country actually having a socialist econony. If the modernization of $\mathrm{J}$ cpan had been carried out later than immediately after 1868, she might have taken a more socialistic approach, instead of taking the option of state capitalism as she actually did. The course of historical development of society is not unilinear, not only within the capitalist camp, but also over the broad spectrum of regines from capj.talism to socialism. Furthermore, the instability thesis Implies that by shifting the 
ideological base of the society new ccurses of economic development of a range of varieties will be opened up and these may significantly differ from the old course which would have been followed in the absence of such a shift.

From the point of view of instability theory it is entirely reasonable that philosophers, political leaders and revolutionaries in the Third World recognize the importance of modification or replacement of the existing ideology. In the case of China sun Yat-sen advocated the Western concepts of nationalism, democracy and people's welfare, Chiang Kai-shek emphasized Confucianism and Protestantism, and Mao Tse-tung accepted Marxism. of these three only Mao was successful in giving rise to a remarkable change in the people's attitude, which resulted, in turn, in an enormous improvement in their economic life. In India, the influence of the idea of human spiritual and social equality in missionary Christianity led Mahatma Jotirao Phule to devote himself to abolishing the Hindu caste hierarchy and formirg a new religious identity, 33 while Mahatma Gandli, also influenced by Christian ideas, tried to improve the lot of the weak and oppressed, especially the untouchables. As a Hindu himself, however, Ciandhi did not wish to abolish the caste systen but fought its evils. He condemned modern Western civilisation, and wanted to preserve the Indian cultural traditions, by opposing the spirit inherent in both socialist and capitalist Industrialism at the time. 34 He laid himself open to cross fire from conflicting forces and was shot dead by a Hindu fanatic. 
Gandhi paid a high regard to heredity because he believed that to disregard the law of heredity would create g:at confusion. This belief caused his reluctance to abolish the caste system, which is the mainstay of traditionalism in India. This attitude, despite his great desire to improve the position of the untouchables, made him very much a gradualist. He could minimize bloodshed in the Indian independence movement by his advocacy of passive resistance. In the same spirit he insisted on the importance of villages as against cities, because he believed that truth and non-violence were only possible in the context of the simplicity of the villages. He also considered that labour was more important than machines, in the industrial development of India. This emphasis was shared by Mao. For Gandhi, independence by passive resistance was independence achieved through the indigenous Indian spirit; the important thing was to stand by themselves without the help of Western civilisation. Gandhi considered that the ancient Indian ethics, which knew nothing of rights but only duties, should be the base for Indian development in the future. He emphasized that all rights derived from duties well performed. 35

It is clear that this philosophy of Gandhi. denounces the civil society, one of the main pillars of Western capitalism, and promotes nationalism. The situation is in strong contrast to that of Japan after 1868. It is true that in Japan too there were many fanatical nationalists who rejected everything western and strictly upheld the Japanese traditions, but okubo Toshimichi, the central figure of the Meiji Revolution, was brave enough to abolish the caste system, which had prevailed more or less rigorously throughout the Tokugawa era (1603-1867). In China Confuclanism was a philosophy for feudalism and had always supported the feudal hierarchy of status, 
but its caste system had not metaphsical justification, unlike its Indian counterpart, which has had such a justification continuously since Aryans first came to India. Therefore, the cast system is more separable from Confucianism in China than it is from Hinduism in India. Furthermore, in Japan the system was fredominant only during the Tokugawa period. By comparison with Gandhi, therefore, ökubo was in a position to terminate more easily a sjsten which had been a major source of econoric inefficiency, By abolishing the caste system ökubo could bring to an end the feudal division of the society into fixed classes; this not only contributed to an upsurge of nationalism, but also released individuals from feudalistic fetters hindering modern individualistic competition. In this way, the Japanese gradually began to recognize the importance of civil society in modern life, though this was not openly acknowledged until the end of World War II.

5. From this we may conclude that the line: of moderate passivity which was taken by Gandhi was not revolutionary enough to make the Indian economy shift itself in the direction cf modern capitalism or socialism. However, unlike the Chinese and the Japanese, Indians are more sincere and serious in their search for truth and salvation. In Hinduism they have developed a magnificent metaphysical theory, that is a religion of caste and renunciation of life. As a Hindu, Gandhi was not an exception; he was possessed by the devil of caste. This is the tragedy of Gandhi, the tragedy of India. Unlike Japan but like China, the introduction of elements of Western ideologies, for example, Protestantism, Socialism or even Marxism, into the indigenous religion is necessary or indispensable for India's economy to develop in a rational and secularly ascetic mannex. 
Myrdal (1972) is also very critical of the caste system. Given the sanction of religion, i.e. of Hinduism, which is even today very powerful among Indians, the caste system isi still strongly influential there, particularly in villages. It segments the society and is, therefore, an obvious obstacle to development. "It fortifies the contempt and disgust for manual work prevalent in all social strata. Since an orthodox Hindu regards not only those who perform this work but everyone outside his own caste as beyond the pale, it also warps and stultifies ordinary human feelings of brotherhood and compassion."36 Naturally, this caste system creates divisions of culture and econonic interests which work against national consolidation. Moroever, according to Myrdal, "we cannot claim that this ideal of a more disciplined nation is shared by a large number of people even among the intellectual elite of South Asia." 37 Thus he concludes that under present conditions in India development cannot be achieved unless the people observe social discipline much more strictly than the prevailing intepretation of: democracy in the region permits. "Too much individual interest, too little public spirit" is the diagnosis for India; it is completely opposite to that for Japan.

In this situation, Gandhi still believed ron-violent social change to be possible by persuading the privileged to abandon their privileges and enter into truly democratic cooperation with the underpriviliged. Quoting from D.R. Gadgil who criticizes such optimism by Gandhi as "little more than revivalism". Myrdal joins with him in saying that "the failure of Gandhi's approach 'lay essentially in not recognizing the need for thoroughly demolishing the older institutional and class forms before a new synthesis could 
be attempted". 38 on the other hand, Myrdal appreciates other aspects of Gandhism. Gandhi rejected not only European products but also the European mode of industrialization. He resembled Mao in rejecting the large-scale factorial mode of production in cities with the use of machines. As has been pointed out above, he emphasized villages and labour instead. Myrdal finds an essential element of rationality in this gospel of Gandhi and says: "the programs for promoting cottage industry as they have evolved in the post-war era have come more and more to represent purposeful and realistic planning for development under the very difficult conditions that prevail".39

It is evident, however, that however brave, ambitious and respectable such a thing might be, it is extremely difficult and expensive to achieve such a growth programme without the help of European civilization. Gandhi's philosophy of making India Indian again by dint of the Indian spirit alone is an obvious antithesis to the Japanese slogan after the Meiji Revolutior, of "Japanese spirit with Western Technology". It is not surprising to see that the instability theory has not worked in Indiai for that theory to work, it requires that a new shift in ideology create secular asceticism and rationalism among the people.

Despite the existence of many articles in siearch of a Protestant ethic analogy in Asia, my book (1982) might claim to be unique in clearly referring to the instability of secular life in response to a change in ideology or a religious reform. In the case of Japan, it has been suggested that such religious sects as Jodo Shinshu and Zen-shu and such ethical movements as Hotoku-kyo and Shingaku are associated with Japan's successful economic achievements. 40 It is 
true that Jodo Shinshu can be considered as Buddhism's version of Protestantism and has played an important role in the secularization of Buddhism in Japan. It is also true, as Bellah has pointed out, that the priests of the Jodo Shinshu sects gave sermons emphasizing the importance of 'inner-wordly asceticism'. As a matter of fact, however, after the defeat of the Ikko uprising (1571-1580) by Nobunaga, Jodo Shinshu (sometimes called Ikko-sh11) possessed little in the way of a desire for social reform, a fierce indignation against evil or a concept of popular salvation. Throughout the Tokugawa era, and even since then, its leaders incluiged themselves in an aristocratic lifestyle. Moreover it is certainly true that Hotoku-kyo and Shingaku were popular among Tokugawa merchants, but Bellah's criticism of Mcclelland, that he is mistaken in concluding that samurai in the Meiji period were devotees of Zen Buddhism, 41 holds just as well for his own discussion of the hotoku-kyo and Shingaku movements. In fact, political leaders and industrialists in the Meiji period were not much influenced by these movements. Meiji Japan was still a samurai society and it was Confucian thought which played the role of the driving force behind modernization in that period. 42

Those articles concerned with the relationsnip between religion and inner-wordly asceticism in the non-occidental areas seem mainly to have tried to identify those religions which have most contributed to enhancing the motivation necessary for entrepreneurial activity, but they have neglected the problem of motivation for asceticism on the workers' side.43 In Weber, as has been seen in an earlier part of this chapter, both are constituent elements of the spirit of the capitalist regime. We may say, therefore; that these articles are 
not genuinely Weberian because they discuss only "the capitalists' spirit" but not "the spirit of capitalism". They are also far from realizing that Weber's Protestantism thesis is essentiatly an instability or knife-edge theorem. Only Bellah (1963) is near to finding the theorem (but has missed it) when he says: "As every reader of the famous [Protestant] essay knows, the material is derived from England primarily, and not from: Germany, where the Reformation remained abortive in important respects and its structural consequences stunted."44 Without the instability theorem it is rather difficult to understand why Japan and the two countries of Korea and Taiwan, both of which have been greatly influenced by Japan in terms of education and worldly behaviour, have been successful in breaking through the barriers to nodernization, whilst China, though accomplishing a brilliant breakthrough under the communist party since the war, is still struggling to complete the work of modernization. Mao failed to bring the cultural revolution to the successful conclusion he hoped for. "The cultural revolution" and "brain washing" look prima facie like Marxist concepts, but in spite of their being concerned with violent activities, they are entirely in place in a Weberian glossary.

6. A dynamic congruence theory may be obtained by combining what I have called the Marxian and Weberian approaches. Let $\mathrm{E}_{\mathrm{t}}$ and $\mathrm{s}_{\mathrm{t}}$ represent the state of the economy in period $t$ and the state of the superstructure in $t$, respectively. According to the Marxian theory, for each $E_{t}$ there is an adequate state of the superstructure $S *$, while the Weberian theory says that there is also a reverse relationship of adequacy between $E$ and $S$, that is, for each given $S_{t}$ there is an adequate state of the Economy $E^{*}$. Let us express these 
two kinds of congruency as $S^{*}=M\left(E_{t}\right)$ and $E^{*}=W\left(S_{t}\right)$, respectively, and assume that there is no time lag in the realization of the Marxian congruence, so that $S *=S_{t}=M\left(E_{t}\right)$, while there is one period of lag in the Weberian one: $E^{*}=E_{t+1}-W_{(}\left(S_{t}\right)$. (This is the assumption for the sake of simplicity. We may alternatively assume that there is some time lag in the Marxian congrufnce too and can mutatis mutandis appply the following argument to this bilaterally lagged system.) Combining these, we have $S_{t+1}-M\left(W\left(S_{t}\right)\right)$ and find that where $W$ is not the inverse of $M$, there is a dynamic movement of $S$ and, hence, of $E$. With a given $S_{0}$ we obtain $E_{1}$ by the Weberian theory. Then the Marxian theory tells us that $s_{1}$ is congruent to $E_{1}$. Similarly, we obtain $E_{2}$ as corresponding to $S_{1}$ and $S_{2}$ to $E_{2}$; and so forth. Thus a movement of superstructure, $s_{1}, s_{2}, s_{3}, \ldots$ and a movement of economy, $E_{1}, E_{2}, E_{3}, \ldots$ are generated from the original state $S_{0}$. In the sequence of the states of econcmy, $E_{t}, t=1$, $2,3, \ldots$ those $E_{t}$ for all $t \leq$ some $t^{\prime}$ would belcing to the same regime, say the capitalist while $E_{t}$ 's for $t>t$ ' might belong to another, say, the socialist. In this case we have a transformation of the economy from capitalism to soclalism.

This is a scheme of historical transforination which is established by using both Marxian and Weberian components. One example of this is Schumpeter's theory of the evolution of society. Contrary to the Marxist theory of revolution whilh maintains that the capitalist regime will finally collapse and be replaced by socialism or communism because economic polarization becomes unacceptable and repeated crises become more and more stormy and explosive, Schumpeter develops the following argument: "the actual and prospective performance of the capitalist system is such as to negative ( $\underbrace{}_{\text {ic }})$ the idea of its breaking down under the weight of 
economic failure, but ... its very success undermines the social institutions which protect it, and 'inevitably' creates conditions in which it will not be able to live and which strongly point to socialism as the heir apparent". 45

In more detail, "capitalism creates a critical frame of mind which, after having destroyed the moral authority of so many other institutions, in the end turns against its own; the bourgeois finds to his amazement that the rationalist attitule does not stop at the credentials of kings and popes but goes on to attack private property and the whole scheme of bourgeois values." 46 In addition, there is the fact that in Europe, where nation states competed for internationally mobile capital, they were in collusion with capital and treated the bourgeois exceedingly favourably. 47 Naturally, such a collusion could also be a target of severe criticism. Monarchs strove for the provision of infrastructural services for industry and commerce in order to gain revenue for themselves. Furthermore, "In a purely bourgeois regime", Schumpeter says, "troops may fire on strikers, but the police cannot round up intellectuals or must release them forthwith; otherwise ... the freedom it [the bourgeois stratum J disapproves cannot be crushed without also crushing the Ereedom it approves. ... In defending the intellectuals as a group ... the bourgeoisie defends itself and its soheme of life. Only a government of non-bourgeois nature and non-bourgeois creed ... is strong enough to discipline them."48 "Freedam of public discussion involving freedom to nibble at the foundations of capitalist society is inevitable in the long run. .... The intellectual group cannot help nibbling, because it lives on criticism ... and criticism 
of persons and of current events will ... fatally issue in criticism of classes and institutions." 49

Once the superstructure of Western capitalism reaches this stage, it is obvious that the economy cannot work in the way it worked when 'the Protestant ethic' and, therefore, 'the spirit of capitalism' prevailed in the society. At this stage, innovation will also have been reduced to routine. Entrepreneurship tends to be depersonalized and automated. "Bureau and committee work tends to replace individual action."50 As in the ringi system of Japanese firms, a very bureaucratic form of decision-making will be adopted. Not only will the entrepreneurial function become obsoletee, but also other strata supporting the regime, such as aristocrats and rentiers, will tend to become powerless and finally disappear. It will become an age of professionals and intellectuals, and, as in Japan, the educational rat race will become hectic and severe:

Such a situation is very remote from that of 1.7 th century England with which Weber is mainly concerned in his famous 'Protestantism article. Let $\mathrm{S}_{0}$ be the superstructure in the 17 th century which has the Protestant ethic as its dominant element and $E_{1}$ the modern capitalist economy which was emerging and groving at that time. Furthermore, let $s_{t}$ be the superstructure with the kind of ethos which, as has just been described above, Schurpeter considers to prevail in mature capitalist economy in its closing years, and $E_{t+1}$ the new economy, which would be in accordance with the superstructure $S_{t}$. Schumpeter speculates that this new economy will be a socialist one. As has been seen before, however, the cajtalist camp is no longer homogeneous now that Japan has establ:shed herself as a Confucian capitalist state. An alternative option is now available. The 'diseased' Western capitalist economy in its final stage might be 
metamorphosed into a more socialistic variety of capitalism of the Japanese type, rather than switching immediately to socialism. Also, Schumpeter neglected the possibility of the appearance of someone Iike Mrs. Thatcher, whose aim is to intervene in the process of metamorphosis in the hope of reviving the victorian ethic and spirit in the late 20th century. In any case, Schumpeter's scheme of transformation of a society from capitalisin to socialism is too simple to be accepted without modification, because the rich menu of future economic systems now available to each modern society is likely to contain several options, from among which a society can choose without undue friction. It is not entirely inconceivable that competitive capitalism, having started with the Protestant ethic, will end in the managerial capitalism of the Confucianist or Japanese type.

Since the time $t$ at which some kind of Schumpeterian transformation is made has not yet come and, hence, $t$ takes on a large value belonging to the future, it is necessary for us to make an empirical analysis for the past and a deductive analysis for the future in order to $f i l l$ in the intermediate stages $\left(S_{i}, E_{i+1}\right), i=1$, $2, \ldots, t-1$, between the Weberian age $\left(S_{0}, E_{1}\right.$ ) and the Schumpeterian age $\left(S_{t}, E_{t+1}\right)$. In this way we might be able to obtain a complete course of dynamic movements of $S$ and $E$ from $O$ to $t$. Moreover, in view of the fact that the superstructure $s$ is not a single entity but a multidimensional complex consisting of religion, culture, international environment and many others, it is extremely difficult to determine the dual relationships $s_{i}-M\left(E_{i}\right)$ and $E_{i+1}=W\left(S_{i}\right)$ which generate sequences $s_{i}, E_{i+1}, i-1,2, \ldots, t-1$. This is a classic point raised by Brentano and Tawney. However, despite the fact that 
controlled experiments are almost impossible in the social sciences, it is still possible to imagine ceteris paribus situitions from which deductive analytical conclusions can be derived by slcilfully applying the method of thought experiment based on the idea of 'verstehen'. In this way we may minimize the ambiguity and arbitrariness unavoidable in this sort of research and may at least obtain a model which is useful for forming a conjecture about the future or a quasi-causal theory of history.

7. Thus, providing that we are satisfied with a rough first approximation in the form of a partial theory, the task of dynamizing the Weberian thesis may not be entirely impossible. In fact, there have been attempts which may be seen as exploring the way to tackle this problem. For example, Wiener (1981) does deal with the cultural background of the decline of the industrial spirit in Britain in the period 1850 - 1980, though this work has to be carefully re-examined in conjunction with economic history analyses, such as those by Church (1980), Deane \& Cole (1967) and others. Viener develops a view which is an alternative to Schumpeter's but does not entirely contradict it. He emphasizes the ambivalent character of the English ethos and writes that this ambivalence placed lasting social and psychological limits on the industrial revolution in England and, in spite of Britain's being a pioneer of modernization, a hostility to industrialism persisted; the prosperity of industry was only short-lived and the age of post-industrialization came soon. This view is not unconnected to that of Weber, who also noticed the ambivalence of the English character: In his words, "through the whole of English society ever since the seventeenth century we see the conflict between the squirearchy, the representatives of "merrie 
old England," and Puritan circles widely fluctuating in their social influence. Both elements, on the one hand an unspoiled naive joy of life, and on the other a strictly regulated, reserved self-control combined with conventional ethical conduct, are even to-day combined to form the English national character". 51 similarly, Wiener points out that while England gave birth to the injustrial revolution and exported it throughout he world, the English themselves were not comfortable with materialistic growth. They have always had the view that England is essentially the countryside; a green and pleasant land. The English way of life stresses "nonirdustrial, noninnovative and nonmaterial qualities." 52 "The English genius, " he writes, "was (despite appearances) not economic or technical, but social and spiritual; it did not lie in inventing, producing, or selling, but in persevering, harmonizing and moralizing." 52

As the superstructure $S$ is multidimensional, it may contain, as it does in the case of Britain, contradictory elements, the spirit of anti-individualism as well as the spirit of capitalism, and this ambivalence creates a dynamism in the economy. Throughout the 19 th and 20 th centuries Britain has more and more been inclined, in the choice between Workshop and Garden, in favour of the latter. In Wiener's own words: "the dominant collective self-image in English culture became less and less that of the world workshop. Instead, this image was challenged by the counter image of an ancient, little-disturbed "green and pleasant land"." Britain all too soon lost the position of Workshop of the World in the competition for econonic hegemony.

In this dynamic process, Wiener says, the "period of recognised economic crisis in Britain was preceded by a century of psychological and intellectual de-industrialisation." 53 Tfis view fits perfectly 
to oux formula incorproating time lag, $E_{t+1}-W\left(S_{t}\right)$. Wiener resembles Schumpeter in as far as they both emphasize cultural elements as one of the major causes of the deciine of industrialism in Britain. "The politicians, civil servants, churchmen, profiessional men, and publicists who did so much to shape modern British political opinion and policy moved in a climate of opinion uncongenial to the world of industry".54 Their images of a very attractive way of life were "geared to maintenance of a status quo rather than innovation, comfort rather than attainment, the civilized enjoyment rather than the creation, of wealth."54 This would obviously give rise to a decline in both Schumpeter's entrepreneurship and Weber's spirit of capitalism. By developing and improving this sort of theory we may eventually obtain a theory of history, or a dynamic theory of social economy which is better than either the Marxist doctrine of historical materialism or the Weberian social theory of the "Protestant ethic" thesis type.

Despite its brllliance, I do not entirely subscribe to Wiener's analysis; we may conceive of another plausible conjecture concerning the "British disease". It is true that his attempts to relate Britain's economic decline to the ambivalence which is found in the English ethos is novel and ambitious. There is no doubt about this. My own conjecture, however, is that the British two-party system is greatly responsible for the decline, though this system may of course be considered as a political reflection, or symbolization, of the anbivalence in the national ethos. Economic desay may be considered as the cost paid by the British people for their keeping the two-party system for the sake of democracy, individualism and liberalism. 
Finaliy it must be stressed that both Marxian and Weberian approaches are indispensable elements in an "extended economics" that I propose. Where no individual is moved by the spirit of maximizing utility and no entrepreneur is strong enough to be loyal to the spirit of maximizing profits, classical or neoclassical theory are nothing more than castles in the air. Even Marx, the most important thinker to advocate an objective theory of economic determinism, assumes that a spirit of capitalism prevails in the economy when he says: "Accumulate, accumulate! That is Moses and the prophets".55 Social ethology, though it is as yet very undeveloped, is an appropriate member of the extended economics. In this magnificent subject, which is inevitably multidisciplinary, it is of course desirable that the component disciplines, economics proper and social ethology, would be methodologically of the same kind.

Fortunately Weber's sociology is constructed along much the same lines as Ricardo's economics, the prototype of contemporary economic theory. In regarding Ricardo as the originator of theoretical economics there is no disagreement among economists. Marxian economists and Walrasian or mathematical econorists, as well as those belonging to the British classical school (including Keynes), are all Ricardian in methodology. They begin by clearly defining the concepts which are used in their economic ana.ysis. These may also be called ideal-types (in Weber's terminology); they are pure or abstract rather than actual or concrete. By using them an economic model is constructed. Of course the model thus constructed is an ideal-type too. Such a model is useful in emphasizing certain aspects of the actual economy and provides devices which help our understanding of the essential mechanisms of the economy. Relations 
between the various ideal-types, or economic laws, are found by deductive logic, or often by using mathematics, without giving much consideration to historical or empirical observation. A substantial part of Weber's sociology is also constructed in a more or less similar way, as is already familiar to us as eccnomists; consequently it would not appear to be very difficult to build a construction which incorporates deductive sociology together with deductive economics .

Any theoretical description of the world based on ideal-types will frequently deviate from the actual world; it is not more than a first approximation to reality. Therefore, whenever we find a serious gap between theory and reality, we must be modest enough to alter the model, so as to obtain a better theory. Although economic theorists are not eager to modify their own models, the revision of a theory in the light of observation is the most essential part of scientific activity. Moreover, economists should learn how to handle historical data from Weber, who started his academfc life as a historian. Then the extended economics we should estabIish is likely to be closer to the historical economics of Adam Smith and Marx, than to the pure economics of Ricardo and Walras. 
1. Guha (1981) p.91

2. Dore (1976) pp. 72-75.

3. Dore $(1976)$ p. 44

4. Macfarlane (1978) pp. 77-78.

5. Trevelyan (1944) p. 100.

6. Trevelyan (1944) p. 206.

7. Tawney (1977) pp. 311-13.

8. Morton (1938) pp. 109-10.

9. Schumpeter (1954) pp. 95-107.

10. Robertson (1933).

11. Hirschmeier and Yuí (1975) pp. 52-56.

12. Schumpeter (1954) pp. 80-81.

13. Weber (1930) p. 64.

14. Otsuka (1955)

15. Weber (1930) p. 52.

16. Fischoff (1968) p. 77.

17. Weber (1920, vol. I) p. 521.

18. Weber (1920, vol. I) p. 527 .

19. Weber (1920, vol. I) p. 534.

20. Weber (1920, vol. I) p. 440.

21. Weber (1921, vol. II) p. 378.

22. Weber $(1920$, vol. I) p. 69.

23. Weber (1920, vol. I) p. 535.

24. Morishima (1982) pp. 1-19.

25. Morishima (1982) pp. 52-87.

26. Weber (1927) pp. 337-343.

27. Htrschmeier and Yuf (1975) p. 44.

28. See for example Hirschmeier and Yui (1975) and Morishima (1982). 
29. Schumpeter (1943) P. 61.

30. Dore (1973) pp. 227-8.

31. Melotti (1977).

32. Concerning simflarities and dissimilarities between capitalist and socialist economies, see Morishima (1976) pp. 1-15.

33. O'Hanlon (1985)

34. Buss (1985) pp. 17-22.

35. Buss (1985) p. 17

36. Myrdal (1972) p. 147.

37. Myrdal (1972) p. 52

38. Myrdal (1972) p. 178.

39. Myrdal (1972) p. 325

40. Bellah (1957) Ch. 5, and Mcclelland (1961) PP. 369-70.

41. Bellah (1963).

42. Morishima (1982) and Golzio (1985) pp. 98-99.

43. For example, the articles contained in Elseristadt (1968) and Buss (1985).

44. Bellah (1963).

45. Schumpeter (1943) p. 61.

46. Schumpeter (1943) p. 143.

47. Hall (1985) p. 102, and Weber (1927) p. 337 of the English version.

48. Schumpeter (1943) p. 150.

49. Schumpeter (1943) p. 151.

50. Schumpeter (1943) p. 133.

51. Weber (1930) p. 173.

52. Wlener (1981) p. 6.

53. Wiener (1981) p. 157.

54. Wiener (1981) p. 159.

55. Marx (1965) p. 595. 


\section{REFERENCES}

[1] Bellah, R.N. (1957) Tokugawa Religicn, Free Press.

[2] Bellah, R.N. (1963) "Reflection on the Protestant Ethic Analogy in Asia" Journal of Sozial Issues, XIX, No. 1, pp. 52-60 (also included in Eisenstadt (1968)).

[3] Brentano, L. (1923) Der wirtschiftende Mensch in der Geschichte, Gesammelte Reden und Aufsätze, E. J. Brill.

[4] Buss, A. E. (1985) Max Weber in Asian Studies, E. J.Brill.

[5] Church, R. (1980) The Dynamics of Victorian Business, George Allen \& Unwin.

[6] Deane, Phyllis and Cole, W. A. (1967) British Economic Growth, 1688-1959, Cambridge University Press, Second

[7] Dore, R. (1973) British Factory, Jap.mese Factory, George Allen \& Unwin.

[8] Dore, R. (1976) The Diploma Disease: Education, Qualification and Development, George Allen \& Unwin.

[9] Durkheim, E. (1976) The Elementary Forms of the Religious Life, George Alien \& Unwin, Second ed.

[10] Eisenstadt, S.N. (1968) The Protestant Ethic and Modernization, Basic Books Inc.

[11] Fischoff, E. (1944) "The Protestant Ethic and the spirit of Capitalism: The History of a Controversy," Social Research, XI, pp. 54-77 (also included in Eisenstadt (1968)).

[12] Golzio, K.H. (1985) "Max Weber on Japan: The Role of the Government and Buddhist Sect" in Buss (1985), E.J. Brill.

[13] Guha, A.S. (1981) An Evolutionary V:Lew of Economic Growth, Oxford University Press.

[14] Hall, J.A. (1985) Powers and Libertiєs, Penguin Books.

[15] Hirschmeier, J. and Yui, T. (1975) Tree Development of Japanese Business 1600-1973, Gecrge Allen \& Unwin.

[16] McClelland, D.C. (1961) Achieving Society, Van Nostrand. [17] Macfarlane, A. (1978) The Origins of English Individualism,
Basil Blackwell.

[18] Marx, K. (1965) Capital, Vol. I. Progress Publishers.

[19] Melotti, U. (1977) Marx and the Th1rd World, Macmillan. 
[20] Morishima, M. (1976) The Economic Theory of Modern Society. Cambridge University Press.

[21] Morishima, M. (1982) Why has Japan 'Succeeded'?, Cambridge University Press.

[22] Morton, A.L. (1938) A People's Histöry of England, Lawrence and Wishart.

[23] Myrdal, G. (1972) Asian Drama: An Inquiry into the Poverty of Nations, Abridged, Vintage Books Edition.

[24] O'Hanlon, R. (1985) Caste, Conflict and Ideology, Cambridge University Press.

[25] ōtsuka, H. (1955) A bibliographical introduction to the Japanese version of $M$. Weber's The: Protestant Ethic and the Spirit of Capitalism. Iwanami Library.

[26] Robertson, H.M. (1933) Aspects of the Rise of Economic Individualism, Cambridge University Press.

[27] Schumpeter, J.A. (1943) Capitalism, Socialism and Democracy, George Allen \& Unwin.

[28] Schumpeter, J.A. (1954) History of Economic Analysis, George Allen \& Unwin.

[29] Tawney R.H. (1977) Religion and the Rise of Capitalism, Pelican Books.

[30] Trevelyan, G.M. (1944). English Social History, Pelican Books.

[31] Weber, M. (1920 vol. I; 1921 vol. II; 1920 vol. III) Gesamelte Aufsatze zur Religionssoziologie, J.C.B. Mohr (Paul Siebeck).

[32] Weber, M. (1927) Wirtschaftsgescilichte,. Abriss der universalen Sozial- und Wirtschaftsgeschichte, 1924, Leipzig; General Economic History (tr. F.H. Knight) Free Press.

[33] Weber, M. (19.30) The Protestant Ethic and the Spirit of Capitalism, George Allen \& Unwin.

[34] Weber, M. (1956) Wirtschaft und Geselischaft, Grundriss der verstehenden Soziologie, J.C.B. Mohr (Paul Siebeck); Economy and Society, ed. G. Roth and C. Wittich, 1978, University of California Press.

[35] Wiener, M.J. (1981) English Culture and the Decline of the Indistrial Spirit 1850-1980, Cambridge University Press. 